\title{
Assessment of Marine Litter along Four Sandy Beaches of Saurashtra Coast, Gujarat, India
}

\author{
K.S. Sukhdhane ${ }^{1 *}$, V. Kripa ${ }^{2}$, S.P. Shukla ${ }^{3}$, K.R. Sreenath ${ }^{2}$, \\ Divu Damodaran ${ }^{1}$ and Vinay Kumar Vase $^{1}$
}

\author{
${ }^{1}$ ICAR-Central Marine Fisheries Research Institute, Veraval Regional Center, Gujarat, India \\ ${ }^{2}$ ICAR-Central Marine Fisheries Research Institute, Kochi, Kerala, India \\ ${ }^{3}$ ICAR-Central Institute of Fisheries Education, Mumbai, India \\ *Corresponding author
}

\section{Keywords \\ Marine litter, \\ Saurashtra, \\ Gujarat, Beaches, \\ Monitoring \\ Article Info \\ Accepted: \\ 20 May 2019 \\ Available Online: \\ 10 June 2019}

\section{A B S T R A C T}

This study aims to quantify the abundance and composition of marine litter found on four sandy beaches of Saurashtra coast, Gujarat during different seasons. The marine litter was collected on bimonthly basis from the coast and categorized into material and usage categories. The marine litter significantly varied temporally and spatially at $P<0.05$. The mean abundance of marine litter was found to be $66.76 \pm 4.24$ items $^{-2}$ (19-158 items m2) and mean weight $22.47 \pm 1.03 \mathrm{~g} \mathrm{~m}-2(4.17-40.18 \mathrm{~g} \mathrm{~m}-2)$ per square meters. The results indicated that, Plastic litter occurs in greatest number in all four stations ranging from 59.71 to $76.98 \%$ of the items collected (Mean $66.82 \%$ ). The temporal variation revealed that, the marine litter abundance varied significantly between the months $(\mathrm{p}<0.05)$. The highest abundance of litter was observed during the post-monsoon months. The major contributing factor for the accumulation of marine litter is the recreational activities which suggest that the land based source $(78.50 \%)$ provides the major inputs to marine litter pollution along the coast. Management efforts, including frequent local waste and marine litter collection, are required to minimize the impacts of marine litter on the environment. The results of the study provide the baseline information about the marine litter pollution and assist the effective mitigation strategies.

\section{Introduction}

Marine litter is defined as "any persistent, manufactured or processed solid material discarded, disposed or abandoned in the marine and coastal environment" (National Academy of Sciences, 1975). Marine litter investigation has been an interesting issue for many researchers over the last few decades with its main focus being on its impact on marine life and human activities.
Accumulation of marine litter is complex, multidimensional and wide spread problem of the $21^{\text {st }}$ century (UNEP, 2011; UNGA, 2012).

Trouwborst (2011) reported that, globally the land based sources contribute about $80 \%$ of the litter in the marine environment whereas almost 20\% coming from the marine based sources. Land-based litter include items washed out in storm water entering the marine environment through rivers, municipal 
drainage systems, ephemeral streams and sewage inputs, as well as items discarded by beach goers and windblown litter (Stefatos et al., 1999; Galgani et al., 2000; Moore and Allen, 2000; Katsanevakis and Katsarou, 2004). It can be transported long distances by ocean currents and tides, and can sink and accumulate on the seafloor (Watters et al., 2010).

In the last few decades, marine litter has been recognized as an indicator of other forms of pollution that pose risks to marine organisms. The amount of marine litter produced is currently a matter of great concern in the developing nations especially in India, where waste management has been considered one of the most environmental problems. The severity of the impacts and growing amount of litter in the marine environment, efforts are currently underway to quantify the amount present in the beaches as a first step for understanding and alleviating the problems. In order to understand the influence the marine litter on beaches and aquatic organisms, many observations for abundance and composition of litter on the shore has been carried out (Golik and Gertner, 1992; Garrity and Levings, 1993; Corbin and Singh, 1993; Debrot et al., 1999; Moore, 2009; Jayasiri et al., 2013a; Jayasiri et al., 2013b; Galgani et al., 2014; Scisciolo et al., 2016.,).

The coastline of Gujarat is sensitive ecosystems encompasses diverse coastal habitats like rocky shores, sandy beaches, mudflats, mangrove forests, coral reefs, sea grass meadows, coastal wetlands, estuarine regions etc. lying amid in the densely populated and highly industrialized region, with intense coastal and shipping activities. There is dearth of information available on litter quantities and distribution in the Gujarat coast and thus its impact on the sensitive marine habitats has not been addressed. There are very few studies with respect to plastic litter along Indian beaches specifically on
Gujarat coast except the one by Kaladharan et al., (2017).

Therefore, the present study aims to assess the distribution, types, and amounts of marine litter among the four beaches along the Saurashtra coast, Gujarat. It is hoped that, this study can fill the gap in the data and knowledge, and thus support efforts to achieve better marine litter management along the coast.

\section{Materials and Methods}

This study was comprised of four beaches located along the coast of Saurashtra of Gujarat which are exposing to different coastal activities viz. tourist activities, fishing activities and environmental conditions. The four beaches (Porbanadar, Madhavpur, Chorwad and Veraval) selected for the present study represent a wide geographical coverage of Saurashtra region of Gujarat (Fig. 1). The four stations were surveyed for marine litter on monthly intervals during March 2017 to March 2018. The state of Gujarat accounts for $1600 \mathrm{~km}$ long coastline with $28 \%$ of sandy beaches and many of these are lying along Saurashtra coast. Four beaches were selected for study due to its ecological significance and religiously importance. The detailed of each beach is given in Table 1 .

At each beach, three replicates measuring 100 $\times 1 \mathrm{~m}$ of the strandline were sampled based on Jayasiri et al., (2013a) and Silva-cavalcanti et al., (2009, 2013) with 100m interval. In each replicates all the items of marine litter were visually collected, counted and classified according to their composition and grouped into six categories (Plastic, Metals, Rubeer, Glass, Natural and Others) (Fig. 2). Based on the Trouwborst (2011) all the marine litter was separated to identify the most likely source. The categories were land based and sea based categories 
Table.1

\begin{tabular}{|c|c|l|l|}
\hline Sr. No & $\begin{array}{l}\text { Level of } \\
\text { Urbanization }\end{array}$ & Beaches & \multicolumn{1}{|c|}{ Ecological Importance } \\
\hline 1 & High & Porbandar & $\begin{array}{l}\text { It is an excellent rocky and sandy beach. } \\
\text { Beach stretches for almost 10km. } \\
\text { It is an hot tourist destination and sees about } 5000- \\
6000 \text { tourist every holidays. } \\
\text { The beach has pristine waters for swimming. }\end{array}$ \\
\hline 2 & Low & Madavpur & $\begin{array}{l}\text { The } 6 \mathrm{~km} \text { long stretch of the beach is among the } \\
\text { most beautiful, sandy beaches of Gujarat. } \\
\text { This beach enjoys international recognition as one of } \\
\text { the best beaches in the world. } \\
\text { Itis one of the major nesting sites for the endangered } \\
\text { Green turtle. }\end{array}$ \\
\hline 3 & Low & Chorwad & $\begin{array}{l}\text { The } 7 \mathrm{~km} \text { long stretch of the beach was once home to } \\
\text { the royal palace of the Nawab of Junagadh. The } \\
\text { beach is famous as idyllic beach destinations in } \\
\text { Gujarat. }\end{array}$ \\
\hline 4 & High & Veraval & $\begin{array}{l}\text { The } 6.5 \mathrm{~km} \text { stretch of Veraval beach is a beautiful } \\
\text { stretch of crystal blue water. } \\
\text { Veraval beach is very famous tourist destination } \\
\text { owing to its religious importance and the pilgrims } \\
\text { visiting the temple also visit the beach. }\end{array}$ \\
\hline
\end{tabular}

\section{Statistical analysis}

The analysis of variance (ANOVA) was carried out to determines for the effects of the months, beach and their interactions at the significance level of $p<0.05$ for the abundance by weight and number of plastic litter along the four stations. Prior to conducting the analysis, a normality test was performed, and data transformation was performed for the non-normal variables. Posthoc tests were performed if the ANOVA results showed a significant difference between the different sites. The abundance of marine litter in all the categorized is expressed in Mean \pm SE. The overall percentage of each category contributing to the total abundance was estimated.

\section{Results and Discussion}

As per the objectives of the study, four commercially and religiously important sandy beaches of Saurashtra were surveyed between the periods of June 2017 to April 2018. A total of 4807 items were found on the four beaches within three transects from all the beaches surveyed in different seasons. The mean distribution of Marine litter (Mean \pm SE) for number and weights from four beaches of was represented in Figure 2 and 3. The significant variations through one way ANOVA (Analysis of variance) revealed that the number (ANOVA, $\mathrm{F}=50.07, P=0.00$ ) and weight (ANOVA, F=34.003, $P=0.00$ ) of items varied significantly between the stations $(p<0.05)$.

The mean abundance of marine litter was found to be $66.76 \pm 4.24$ items $\mathrm{m}^{-2}(19-158$ items $\mathrm{m}-2)$ and mean weight $22.47 \pm 1.03 \mathrm{~g} \mathrm{~m}-$ 2 (4.17-40.18 g m-2) per square meters. Although the same types of waste occurred on 
all the beaches, the mean amounts varied significantly according to level of the urbanization and recreational activities. These mean litter values are in line with the finding obtained from the other study carried out in SW Black sea coast, Northern Turkey (1.70 197.25 items $\mathrm{m}^{-1}$ ) Topcu et al., (2013), Balearic islands, Spain (8-132 items $\left.\mathrm{m}^{-1}\right)$ Martinez-Ribes et al., (2007), Cassino beach of Brazil (0.3-60.7 items m$\left.{ }^{-1}\right)$ Wetzel et al., (2004), Bottless Bay, Papua New Guinea (1.2-78.3 items $\mathrm{m}^{-2}$ ) Smith, (2012). In general, the values of marine litter accumulation in the present study showed that the beaches have high influences of the litter and the quantity is comparably higher than the other studies. It can be characterized by the floatation of litter towards the beach, high uses of coast by the tourist visiting for the recreational purpose hence persisting the litter over time.

The mean abundance of marine litter in Porbandar coast was found $95.16 \pm 6.28$ items $\mathrm{m}^{-2}\left(36-140\right.$ items $\left.\mathrm{m}^{-2}\right)$ by items and $24.94 \pm 1.37 \mathrm{~g} \mathrm{~m}^{-2}\left(13.99-33.19 \mathrm{~g} \mathrm{~m}^{-2}\right)$ by weight. The highest abundance of plastic litter was recorded in Veraval coast with $97.66 \pm 6.65$ items $\mathrm{m}^{-2}\left(66-158\right.$ items $\left.\mathrm{m}^{-2}\right)$ by items and $31.59 \pm 1.17 \mathrm{~g} \mathrm{~m}^{-2}(19.84-40.18 \mathrm{~g}$ $\mathrm{m}^{-2}$ ) by weight. The lowest abundance of number of items $\mathrm{m}^{-2}$ was recorded in the Madhavpur coast with mean abundance of $34.88 \pm 2.25$ items $\mathrm{m}^{-2}$ (19-54 items $\left.\mathrm{m}^{-2}\right)$ whereas the lowest weight was recorded in the Chorwad coast with mean weight of 13.07 $\pm 0.59 \mathrm{~g} \mathrm{~m}^{-2}\left(8.48-17.30 \mathrm{~g} \mathrm{~m}^{-2}\right.$ ) (Fig. 4).

During all the sampling months and all the four different stations, plastic litter was predominated in the marine litter collected (Fig. 5) ranging from 59.71 to $76.98 \%$ of the items collected (Mean 66.82\%). Similar to other findings, Jayasiri et al., (2003a. 2003b); Santos et al., (2009); Zhou et al., (2011); Liu et al., (2013); Leite et al., (2014); Adydin et al., (2016) founds a higher abundance of plastic litter (50-90\%) during their study period. The abundance of plastics along these beaches especially Porbanadar and Veraval can be attributed with beach visitors, coastal inhabitants and recreational activities contribute to the major sources of litter pollution on beaches in developing countries due to their littering behavior and high usage of plastics. The plastics categories of marine litter classification also include the Styrofoam which was found in high quantity in Veraval and Porbanadar coast which can be attributed to the fishing activities all along the coast. Most of the marine litter was discarded mainly by the locals and by the tourist, which explains high quantities among these two beaches. Marine litter in Madhavpur and Chorwad beach has less accumulation which can be considered as the reference for other two beaches. The quantity of Metals was found $3.27 \%$ (0.05 - 4.11\%), Rubber $4.39 \%$ $(3.39-4.78 \%)$ and Glass $4.18 \%(3.11-4.84 \%)$ respectively.

The temporal variation revealed that the marine litter (ANOVA, $F=2.16, P=0.05$ ) and weight (ANOVA, $\mathrm{F}=2.32, \quad P=0.05$ ) abundance varied significantly between the months $(p<0.05)$. A comparison based on the number of items among all four stations indicated a consistent temporal trend. The highest abundance of items was observed in the month of August $\left(88.50 \pm 14.86\right.$ items m$\left.^{-2}\right)$ and October $\left(72.58 \pm 10.59\right.$ items $\mathrm{m}^{-2}$ ) (Postmonsoon) months than that of other months while by weight also significantly highest abundance was observed in August (26.10 \pm $\left.2.41 \mathrm{~g} \mathrm{~m}^{-2}\right)$ and December $(24.33 \pm 2.65 \mathrm{~g}$ $\mathrm{m}^{-2}$ ) than in other months (Fig. 6). The lowest litter density was observed in the months of summer $\left(57.75 \pm 7.72\right.$ items $\left.\mathrm{m}^{-2}\right)$. A highest number of large sized litters were observed in post-monsoon for many sites compared to those in other seasons. A general trend was that stations on the eastern side of the study area seemed to receive more local than foreign litter. The high litter accumulation 
during post-monsoon months can be attributed with monsoon and heavy onshore wind speeds that increases the wave heights resulting into the traps of plastics on the shores. The seasonal fluctuation in the litter accumulation can be explained by the resuspension and transport of plastics and other objects on to the shores during postmonsoon months.

Identification of sources of marine litter from the beaches is a primitive step towards the litter solution. In the present study, the overall $78.5 \%$ of marine litter was land based while the remains $21.5 \%$ were based from the seabased sources was observed during the study
(Fig. 7). The ability to define the sources of marine litter based on the composition depends, at least partially, how the conservationist are assume for. The increased sources of land based litters increased during the post-monsoon season. Porbandar and Veraval beach represents an area with high beach usage as compared to Madhavpur and Chorwad beach, reason being that it is easily accessible through road and people visit these beaches frequently. The majority of the litter recovered emanates from domestic, recreational and fishing activities which indicate very high anthropogenic pressure on the beaches.

Fig.1 Sampling station

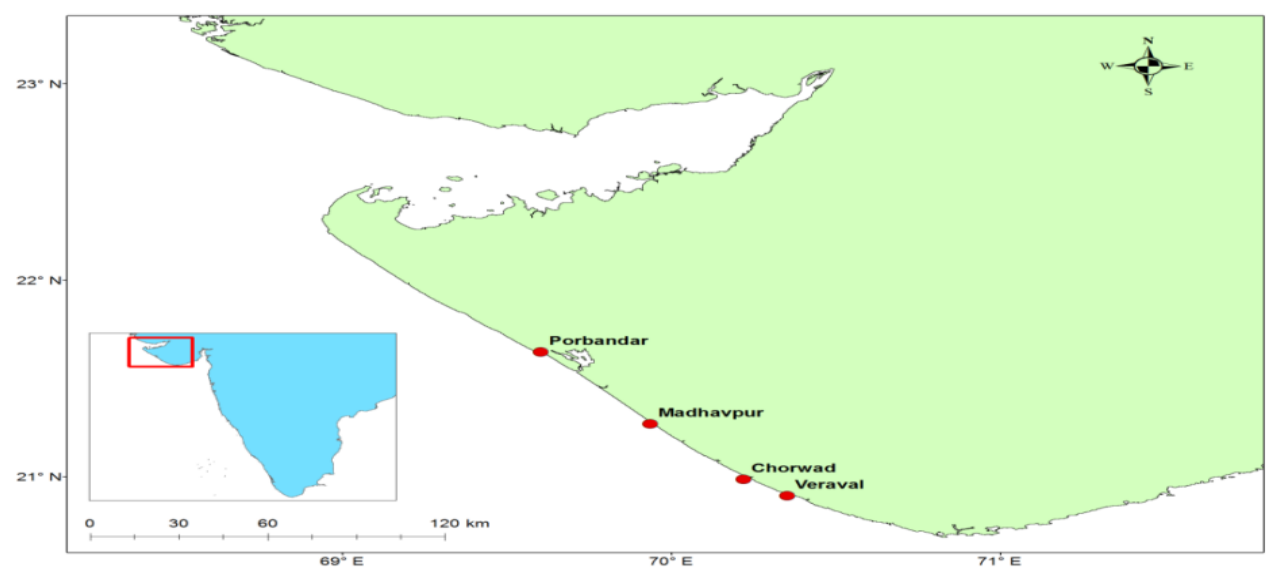

Fig.2 Accumulation of marine litter along Porbanadar Coast

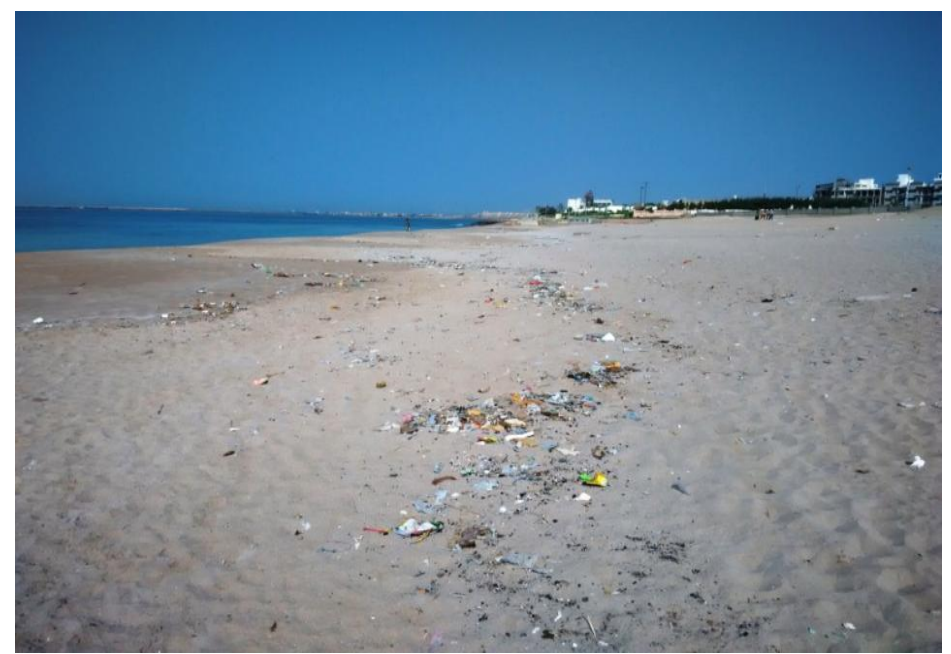


Fig.3 Spatial variations of marine litter abundance (Mean \pm SE) by number of items in four sampling stations (Bars with different letters in lowercase vary significantly among the beaches for the number of items in uppercase $(P<0.05)$

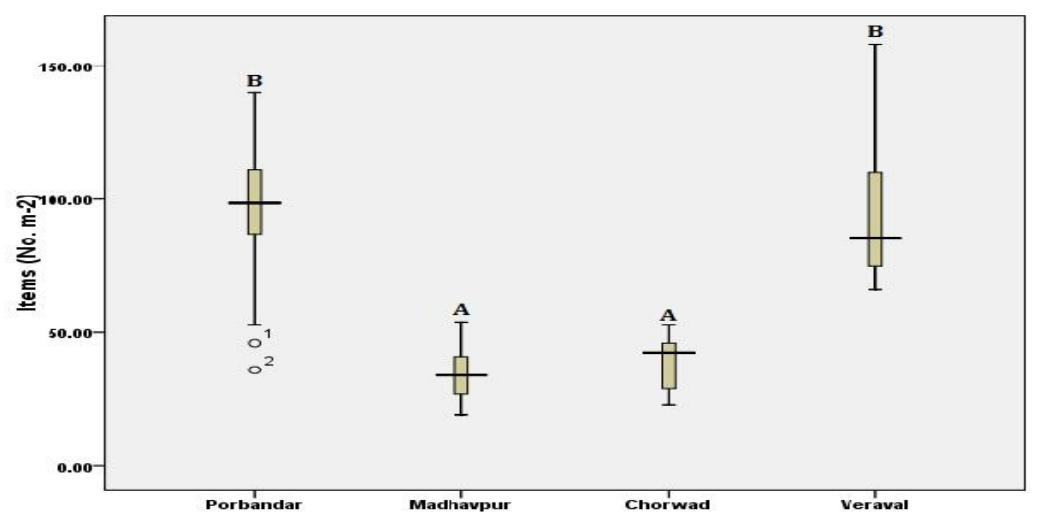

Fig.4 Spatial variations of Marine litter abundance (Mean \pm SE) by Weight of items in four sampling stations. (Bars with different letters in lowercase vary significantly among the beaches for the number of items in uppercase $(P<0.05)$

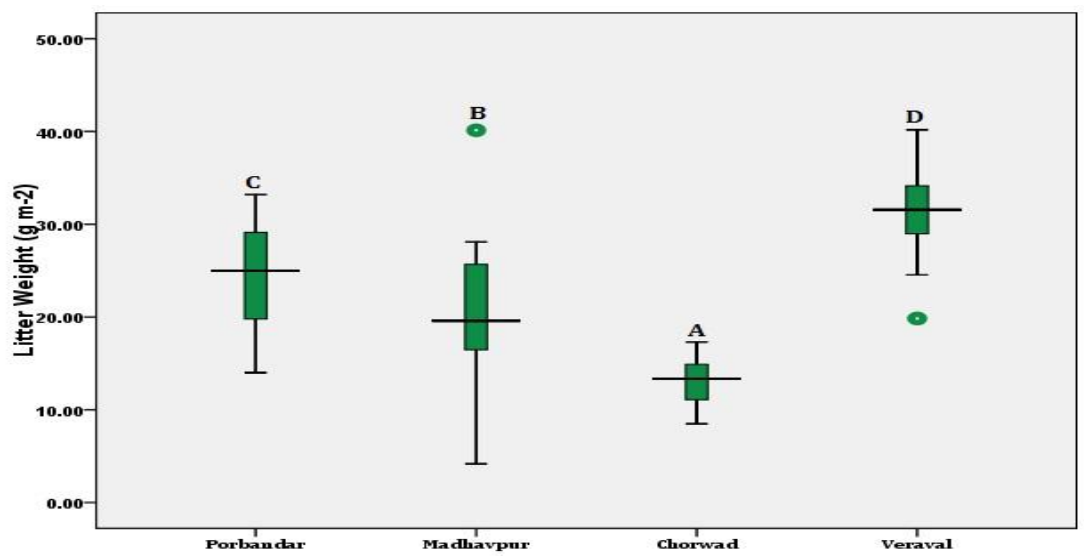

Fig.5 The average abundance of marine litter quantity in (Percentage) in the study area

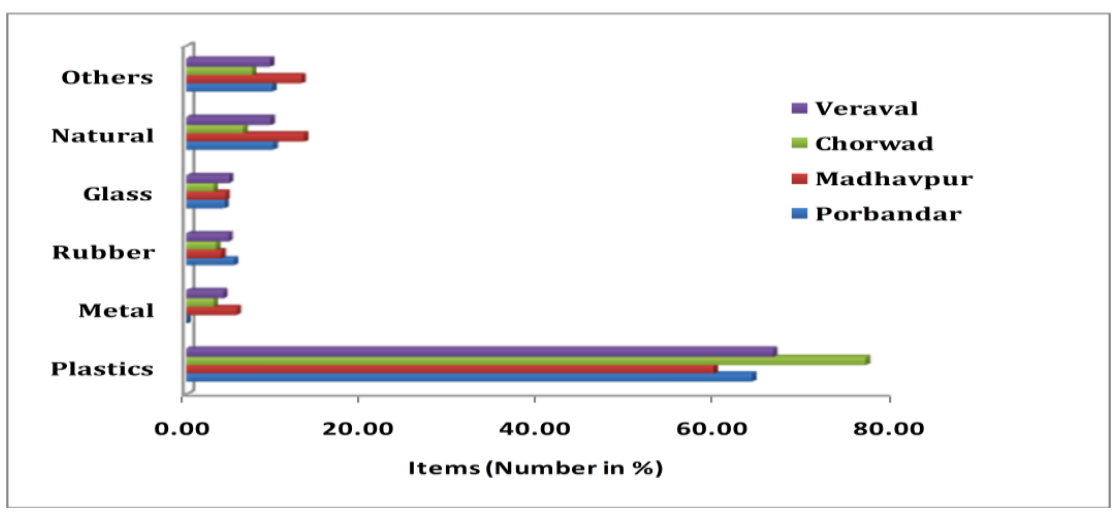


Fig.6 Temporal Variations in Marine litter abundance (Mean \pm SE) by weight and number of items in four beaches of Gujarat coast from June 2017 to April 2018. Bars with different letters in uppercase vary significantly among the months for number and lowercase by the weight

$$
(p<0.05)
$$

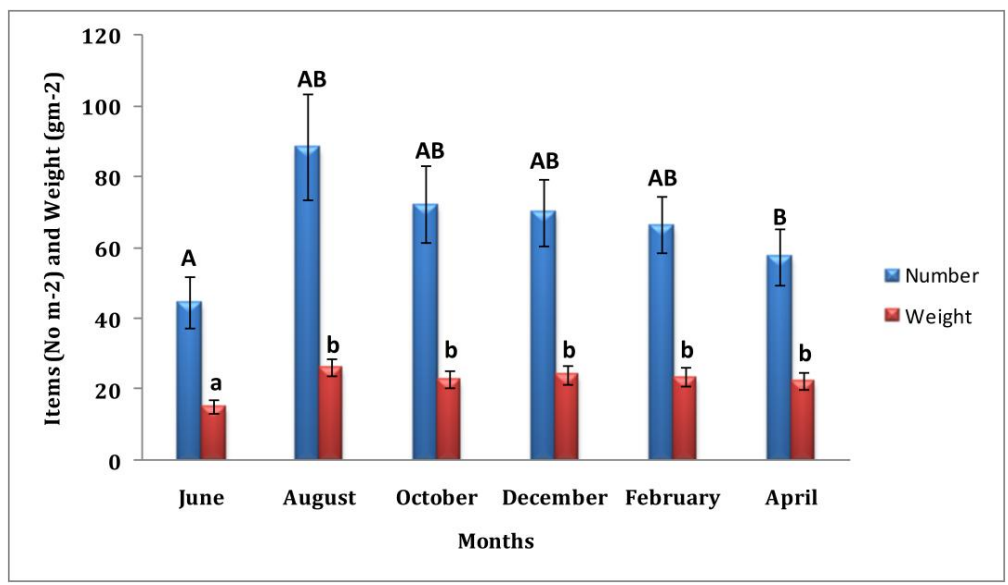

Fig.7 Land-based and sea-based sources of marine litter from the four important beaches of Gujarat coast

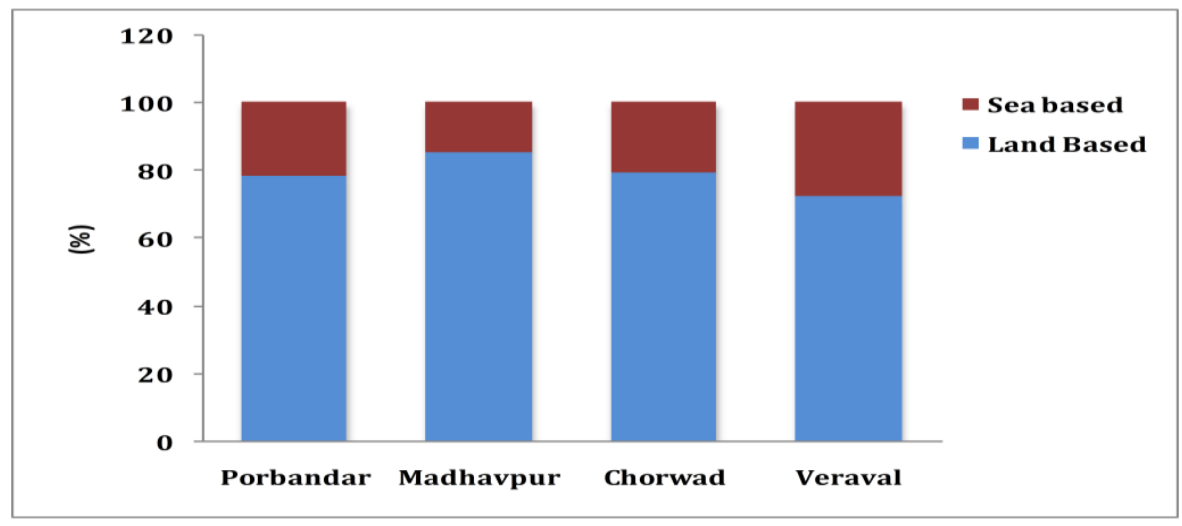

Conclusion of the study is as follows:

In present study, we have reported composition, quantities and distribution of marine litter along four important beaches of Gujarat. The observation of both - number and weight of items, characterized more precisely the contribution of Marine litter to the coastal zone pollution, which is essential for the improvement of Marine Litter management. Plastic was dominated items in the total marine litter from the coast. Majority of marine litter originates from land based sources and activities, the primary emphasis should be given to controlling marine litter should focus on preventing the inflow of litter in to the sea. Taking into the account the absence of earlier study in these areas, our results can provide background information for future assessment and the implementation of management actions to mitigate the problems associated with marine litter. Management efforts, including public awareness and encouraging changes is attitudes related to marine litter management are very essential components in efforts to 
mitigate the presence of marine litter in marine and coastal environments.

\section{Acknowledgment}

The authors gratefully acknowledge Indian Council of Agricultural Research (ICAR), Govt. of India, New Delhi for the scientific and technical support to carry out work. Authors express sincere thanks to the Director, ICAR-CIFE and ICAR-CMFRI for facilities and support. The author is sincerely thanks to all the supporters of ICAR-CMFRI, Veraval and CIFE, Mumbai for their kind cooperation.

\section{References}

Aydın, C. C., Guven, O. O., Salihoglu, B. B., Kideys, A. A. (2016). The influence of land use on coastal litter: an approach to identify abundance and sources in the coastal area of Cilician Basin, Turkey. Turk. J. Fishe. Aquat. Sci. 16, 29-39.

Corbin, C. J. and Singh J. G. (1993). Marine debris contamination of beaches in St. Lucia and Dominica. Mar. Poll. Bull., 26(6), 325-328.

Debrot A. O., Tiel A. B., Bradshaw J. E. 1999. Beach Debris in Curacao. Mar. Poll. Bull., 38(9), 795-801.

Galgani, F., Leaute J. P., Moguedet P., Souplet A., Verin Y., Carpentier A., Goraguer D., Latrouite D., Andral B., Cariou Y., Mahe j. C., Poulard J.C., Nerisson P. (2000). Litter on the sea floor along European coasts. Mar. Pollut. Bull., 40, 516-527.

Garrity, S. D., and Levings S. C. (1993). Marine debris along the Caribbean coast of Panama. Mar. Pollut. Bull., 26(6), 317-324.

Golik, A., Gertner, Y. (1992). Litter on the Israeli coastline. Mar Environ Res., 33(1), 1-15.
Jayasiri, H. B., Purushothaman C. S., Vennila A. (2013a). Plastic litter accumulation on high-water strandline of urban beaches in Mumbai, India. Environ Monit Assess., 185, 7709-7719.

Jayasiri, H. B., Purushothaman C. S and Vennila A. (2013b). Quantitative analysis of plastic debris on recreational beaches in Mumbai, India. Mar. Pollut. Bull., 77, 107-112.

Kaladharan P., Vijayakumaran K., Singh V. V., Prema D., Asha P. S., Sulochanan B., Hemasankari P., Loveson Edward L., Padua S., Veena S., Anasukoya A. and H. M. Bhint. (2017). Prevalence of marine litter along the Indian beaches: A preliminary account on its status and composition. J. mar. Biol. Ass. India. 59(1), 19-24.

Katsanevakis, S. and Katsarou A. (2004). Influences on the Distribution of Marine Debris on the Seafloor of Shallow Coastal Areas in Greece (Eastern Mediterranean). Water Air Soil Pollut., 159(1), 325-337.

Leite, A. S., Santos, L. L., Costa, Y., Hatje, V. (2014). Influence of proximity to an urban center in the pattern of contamination by marine debris. Mar. Pollut. Bull. 81, 242-247.

Liu, T. K.T. K., Wang, M. W. M. W., Chen, P. P. (2013). Influence of waste management policy on the characteristics of beach litter in Kaohsiung, Taiwan. Mar. Pollut. Bull. 72, 99-106.

Martinez-Ribes, L., Basterretxea, G., Palmer, M., Tintore, J. (2007). Origin and abundance of beach debris in the Balearic islands. Sci. Mar. 71, 305314.

Moore, S.L., and Allen M. J. (2000). Distribution of anthropogenic and natural litter on the mainland shelf of the Southern California Bight. Mar. Pollut. Bull. 40, 83-88 
Moore, E., Lyday, S., Roletto, J., Litle, K., Parrish, J., Nevins, H., Harvey, J., Mortenson, J., Greig, D., Piazza, M., Hermance, A., Lee, D., Adams, D., Allen, S. and Kell, S. (2009). Entanglements of marine mammals and seabirds in central California and the north-west coast of the United States 2001-2005. Mar. Pollut. Bull. $58,1045-51$.

Moore, C.J., Moore, S. L., Leecaster, M. K., Weisberg, S. B. (2001). A comparison of plastic and plankton in the North Pacific central gyre. Mar. Pollut. Bull.42(12), 1297-1300.

NAS (National Academy of Sciences). (1975). Marine litter. In: Assessing potential ocean pollutants. A report of the Study Panel on Assessing Potential Ocean Pollutants to the Ocean Affairs Board, Commission on Natural Resources, National Research Council, National Academy of Sciences, Washington, DC.

Santos, I. R., Friedrich, A. C., Do Sul, J. A. I. (2009). Marine debris contamination along undeveloped tropical beaches from northeast Brazil. Environ. Monit. Assess. 148, 455-462.

Scisciolo, T., de Mijts, E. N., Becker, T., Eppinga, M. B. (2016). Beach debris on Aruba, Southern Caribbean: attribution to local landbased and distal marine-based sources. Mar. Pollut. Bull. 106, 49-57.

Silva-Cavalcanti, J.S., Araujo, M. C. B., Costa, M. (2009). Plastic anthropogenic litter on an urban beach - a case study in Brazil. Waste Manage. Res. 27, 93-97.

Silva-Cavalcanti, J. S., Araújo, M. C. B., Costa, M. (2013). Medium-term patterns and trends of solid waste contamination on the beach of Boa Viagem, Northeast Brazil. Q. Environ. Geosci. 4, 17-24.
Silva-Iniguez, L., and Fischer, D. W. (2003). Quantification and classification of marine anthropogenic litter on the municipal beach of Ensenada, Baja California, Mexico. Mar. Pollut. Bull. 46, 132-135.

Smith, S.D., (2012). Marine debris: a proximate threat to marine sustainability in Bootless Bay, Papua New Guinea. Mar. Pollut. Bull. 64 (9), 1880-1883.

Stefatos M., Charalampakis M., Papatheodorou G., Ferentinos G. (1999). Marine debris on the sea-floor of the Mediterranean Sea: examples from two enclosed gulfs in Western Greece. Mar. Pollut. Bull. 36, 389393.

Topcu, E. N., Tonay, A. M., Dede, A. A., Ozturk, A., Ozturk, B. (2013). Origin and abundance of marine litter along sandy beaches of the Turkish western Black Sea Coast. Mar. Environ. Res. $85,21-28$.

Trouwborst, A., 2011. Managing marine litter: Exploring the evolving role of International and European Law in confronting a persistent environmental problem. Merkourios: Utrecht Journal of International and European Law. 27,4-18.

UNEP, (2011). Assessment of the status of marine Litter in the Mediterranean Sea. UNEP (DEPI)/MED WG.357/Inf.4 12 April 2011， 55 pages.

UNGA, (United Nations General Assembly) (2012). "The Future We Want"Resolution Adopted by the General Assembly A/RES/66/288.

Watters, D. L., Yoklavich, M. M., Love M. S., Schroeder, D. M. (2010). Assessing marine debris in deep seafloor habitats off California. Mar. Pollut. Bull. 60, 131-138.

Wetzel, L., Fillmann, G, Nienchesky, L. 
(2004). Litter contamination on the Brazilian southern coast: Processes and management perspectives. Environ. Sci. Pollut. Res. Int. 21, 153164.

Zhou, P., Huang, C., Fang, H., Cai, W., Li,
D., Li, X., Yu, H. (2011). The abundance, composition and sources of marine debris in coastal seawaters or beaches around the Northern South China Sea (China). Mar. Pollut. Bull. 62, 1998-2007.

\section{How to cite this article:}

Sukhdhane, K.S., V. Kripa, S.P. Shukla, K.R. Sreenath, Divu Damodaran and Vinay Kumar Vase. 2019. Assessment of Marine Litter along Four Sandy Beaches of Saurashtra Coast, Gujarat. Int.J.Curr.Microbiol.App.Sci. 8(06): 2623-2632. doi: https://doi.org/10.20546/ijcmas.2019.806.315 